ARTICLES ARTÍCULOS

Copyright $\odot 20123$

SBPjor / Associação Brasileira de Pesquisadores em Jornalismo
BETWEEN BITS AND DOLLARS:

\section{challenges for financing contemporary photojournalism}

\author{
JOSÉ AFONSO DA SILVA JÚNIOR \\ Universidade Federal de Pernambuco \\ JOÃO GUILHERME DE MELO PEIXOTO \\ Universidade Federal de Pernambuco
}

ABSTRACT - Photojournalism is currently undergoing the largest set of changes to its productive chain since its incorporation to digital and network processes. These changes affect the means of production, edition and circulation of content and create new challenges and purposes for the activity. In this study, we have found that going beyond ontological issues, aspects related to economics and funding of photojournalism are also changing. As a method of analysis, we compare the possibilities on this framework to the traditional model used by newspapers and magazines, at a time we can call preconvergent photojournalism. Additionally, we aim to point out the main alternatives to these trends. Keywords: Photojournalism. Digital convergence. Financing. Circulation.

\title{
ENTRE BITS E DÓLARES: desafios para o financiamento da produção fotojornalística contemporânea
}

RESUMO - A atividade fotojornalística atravessa atualmente o maior conjunto de alterações na sua cadeia produtiva desde que foi agregada aos processos digitais e em rede. Esse conjunto de mudanças atinge os meios de produção, edição e circulação de conteúdo e estabelece para a atividade novos desafios e propostas. Neste trabalho observamos que, para além das questões de ordem ontológica, os aspectos relacionados à economia e ao financiamento da produção fotojornalística mostram-se igualmente em transformação. Como método de análise, busca-se comparar as possibilidades em tela, com o tradicional modelo usado por jornais e revistas ilustradas, em um momento em que podemos chamar de fotojornalismo pré-convergente. De modo complementar, objetiva-se indicar as principais alternativas dessas novas tendências.

Palavras-chave: Fotojornalismo. Convergência digital. Financiamento. Circulação fotojornalística.

\section{ENTRE BITS Y DÓLARES: retos para la financiación de la producción fotoperiodística contemporánea}

RESUMEN - La actividad fotoperiodística atraviesa actualmente el mayor conjunto de alteraciones en su cadena de producción desde que fue agregada a los procesos digitales y en red. Este conjunto de cambios afecta a los medios de producción, edición y circulación de contenido, y determina nuevos retos y propuestas para la actividad. En este estudio observamos que, además de las cuestiones ontológicas, los aspectos relacionados con la economía y la financiación de la producción fotoperiodística también se encuentran en proceso de transformación. Como método de análisis, comparamos las posibilidades en discusión con el modelo tradicional utilizado por periódicos y revistas ilustradas, en un momento que podemos calificar de fotoperiodismo preconvergente. De manera complementaria, se pretende indicar las principales alternativas de estas nuevas tendencias.

Palabras clave: Fotoperiodismo. Convergencia digital. Financiación. Circulación fotoperiodística. 


\title{
PRESENTATION
}

\author{
It is absolutely ridiculous to say that \\ photojournalism is dead. It's definitely changing, \\ but I think that's exciting. The modes of delivery and \\ consumption are changing, but \\ there's a lot of great work being done.
}

David Walter Banks

Interactivity. Hypertextuality. Convergence. These are concepts and practices playing in the communications scenario over the last years. They are going through changes, especially regarding the audience's relationship with the media, going from an analog, non-interactive and non-participatory logic to a diverse, digital, interactive, participatory one, where multiple sources and audiences can be accessed.

If we look at photojournalism specifically, these changes are transforming the spheres of production, publication and circulation of photojournalism. New technologies for capturing images combined to a new consumer profile show that the sustainability of a production model in photojournalism takes more than a click. The photograph now acts as a gateway to audio and text information, which may be related to increasing subjectivity in content production. And this all happens in an interactive, non-linear, hypertextual, converged way...

\begin{abstract}
(...) Photojournalism currently consists of an expanded set of practices, where not only the uniqueness of the photographer as the aggregator of a certain set of skills is brought into question, but he turns out to be not only a photographer, but an analyst and constructor of systems that integrate digital and photographic technologies in a world that is completely binary about the production, processing and circulation of images. (SILVA JUNIOR, 2008)
\end{abstract}

Going beyond a simple change in devices, the problem incorporates a culture of uses and production chain of news photography. But beyond that, the point is, how to create sustainable models for photojournalistic production? Although it has been adjusted to the new reality of a historically established set of routines, profound changes intertwine with new prospects that involve financing of increasingly bold projects, which emerge from outside the established chain. This is not only about the technological issues (more modern cameras, more 
advanced editing software), but also about issues relevant to the current methodology of the activity. Thus, establishing emerging forms of funding must be in synch with the horizon of contemporary photojournalism.

By analyzing the changes brought about by the development of new financing models for contemporary photojournalistic production, we unfold the interpenetration of steps of production and financing on the same pole of a complex equation. In the current scenario, new models of audience participation (with an audience that has proven significantly selective and active), linked to the diversification of media models in multi-platform, result in experiences which already assimilate alternatives for financing and circulation of photojournalism.

In order to point out some of these changes, this article discusses two cases, which present alternative financing models for photojournalistic production. The first one (Flattr) can be defined as a payment microplatform designed to bring contents closer to consumers. As for the Emphas.is Web site (a platform dedicated to seeking funding for photojournalistic projects only), it taps into an intimate connection between audience and content producers to provide an approach that offers exclusive content production for the user, thus highlighting the role of funders in the chain of photojournalistic production.

\section{BETWEEN THE PAST AND NOW: FROM THE ADVERTISING MODEL TO PARTICIPATIVE AUDIENCE}

The managing and funding model of journalistic production has historically evolved intermingled with advertising. Labelled "bilateral market" by economists, the equation to understand these exchange relationships are based on a binomial where two distinct groups of users support each other synergistically. Advertisers pay the media to gain access to consumers, which, in turn, support the advertisers. In the end, consumers pay, but only indirectly, through higher prices paid by producers due to their marketing costs (ANDERSON, 2009).

As a first subject for analysis: production and financing of the same content would necessarily connect to the same pole of the equation. The development of journalism therefore appears mediated by advertisers that support the consumer relationship with shareholders, who in turn hold the financial resources. For over a century, this traditional management model used by media companies returned profits which hit the margin of twenty to thirty percent on the gross investment (CAMPBELL, 2009). However, some issues have always been present: 
a) Where would readers be placed in this equation?

b) What is the role played by readers?

c) Who decides what will be published - advertisers?

Shareholders? The audience?

d) Are there other forms of funding for journalistic production?

Some of these issues have grown ever more pressing during most of the twentieth century when, due to the popularization of other media such as radio and television, the circulation of newspapers had a sharp decline, especially in the United States, impacting investments made by advertisers.

Print advertising, which still accounts for the lion's share of newspaper revenue, declined gently as a percentage of all ad spending from 1950 to 90 , as television grew in importance. Starting in 1990, well before the rise of the web as a competitor for ad dollars, newspaper ad revenues went into a sharp decline, from 26 percent of all media advertising that year to what will likely be around 10 percent this year (2008). (CAMPBELL, 2010)

The scenario appears all the more serious when we look at current statistics. Between 2001 and 2008, newspaper circulation fell by more than $13 \%$ (thirteen percent) among daily papers and $17 \%$ (seventeen percent) for Sunday editions (GITLIN, 2010).

Figure 1 Graph showing the decline in newspaper circulation in the U.S. market

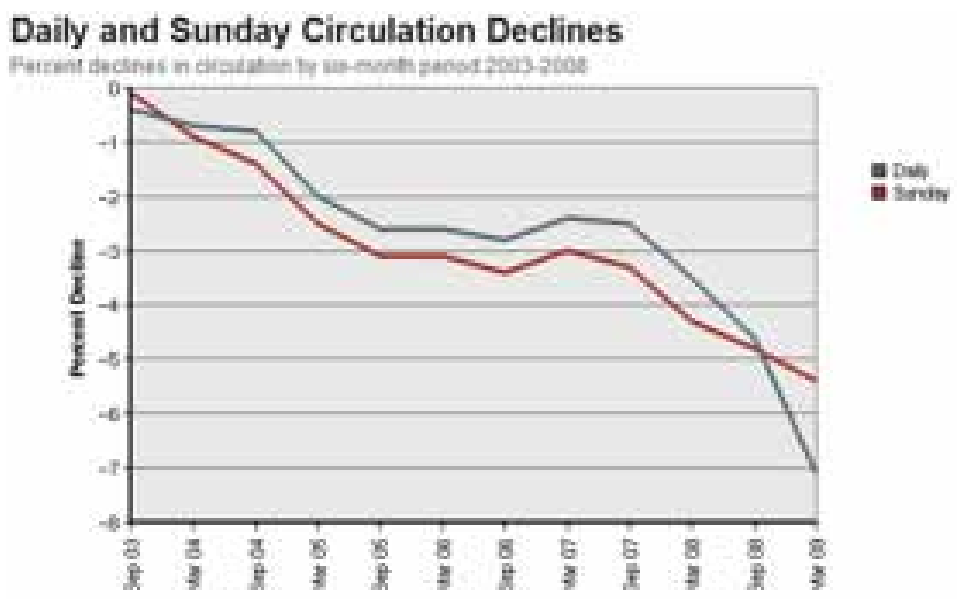


At the origin of these changes, the World Wide Web has revolutionized the structures of information production and circulation. The most dramatic shift is certainly the end of the dualism between producers and consumers, as they no longer correspond to opposing sides of a relationship based on unilateralism between production and consumption. Not only has the web provided users with the opportunity to select what they want to hear, see or read, but also to create and distribute such content without necessarily resorting to traditional sources of production financing and circulation.

As a second point, while this perspective points to a crisis bias of traditional media supported by the model of massive audience, it also opens another perspective, one that counterbalances it with a form of funding that is open to the diversification of multi-platform media models. Going further, establishing the position where the core information unit must be placed seems more important than choosing specific outlets, or rather, production chains that necessarily bind content, platform, and circulation together. It is a transformation where the dynamics of participation and interaction pervade the path from which the information is disseminated and circulated. To understand journalism under this focus is to face it more as an ongoing open process than simply as a product.

And how is photojournalism to be defined as all these changes come about? In close connection to the fields of photography and journalism, photojournalism draws its character from information and news. According to Jorge Pedro Souza, photojournalism "is meant to report, provide context, build knowledge, inform, establish or convey points of view (opine) through event photography and coverage of newsworthy subjects" (SOUZA, 2004). That means that since its beginnings, such values as newsworthiness, clarity and relevance to the subjects presented are part of the grammar and - why not - the ontology of photojournalistim itself.

However, the development of information technology coupled with the expansion of Internet and the World Wide Web brought about changes in photojournalistic newsmaking, as those who produce and those who use the images. In market relations increasingly balanced by the likelihood towards authority, digital culture proposes participation levels where the user / reader / receptor now records, and not only transcodes more information (RITCHIN, 2009).

These aspects unfold directly into the changing context of photojournalism over the last 20 years. Parallel to an increasingly 
progressive adoption of digital technology in the newsroom, there has been a clash of generations of photographers, a transition from one time to another, a tension mapped by forces of resistance to the imposition of a digital photography workflow, on the one hand, and on the other hand, the accession of photographers with a symbolic cognitive model already aligned with the framework of a network society. From 1992, with the introduction of the first digital cameras in newsrooms, until around 2003, when the last remaining analogue equipment was phased out, this transition did actually take place, which does not mean that it was smooth.

As these changes occurred, photographers started to build part of their repertoire with operating grammars arising precisely from the informational area, since they were required to learn how to deal with data systems, file transfers, compatibility between devices, in addition to the symbolic ability to identify what is newsworthy and what can be translated visually. This new reality of multi-skilled professionals that mix abilities from diverse areas of knowledge and convergent practices in technology and in a fully redefined set of professional skills not only reoriented the field of expertise, but also redirected the compass of relations that dictate how, where and which articulations are possible in the production chain of photojournalism.

As a background tool, the photojournalistic record enlarges the horizons to be captured not only with the perfection of pictures that depict what is imperceptible to the eye, but also by pushing further into new spheres of meaning, new subjects, approaches and horizons of coverage (MUNHOZ, 2005). This bias, for some sectors of photojournalism, represented a profound change of routines in newsmaking. Thus, as the possibilities expand for inputting amateur material through experiments as "the reader's photo", for instance, the prospect for other fronts of the trade is devastating. Major agencies and specialized agencies are caught in a false move: a direct threat to its distinctive quality of producing and circulating images at great speed and spreadability (SILVA JR., 2006).

This threat, based on the diversity of autonomous poles of emission (LEMOS, 2007), allowed for the emergence of a diversified range of visibility and is able to circulate images in a manner comparable to that of major agencies given the increasing popularity, expanding internet access and cheapening cost of equipment. The crisis of the Gamma agency, which closed down in 2009 , is symptomatic of a mismatch in the agency model and, consequently, that of massive funding of images by twentieth-century photojournalism standards, rather than a crisis in 
photojournalism as an activity itself. It is a crisis of press photography because the press as a whole is not in its best days; yet photojournalism is well alive, either as a speech, or as practice, or even a style, and is finding its ways.

But how to define the phenomenon of digital convergence in journalism? While it still presents itself in diverse forms, we can refer to Salaverría, García Avilés y Masip (2007) for a theoretical background to support our research.

\begin{abstract}
Media convergence is a multidimensional process that, facilitated by the widespread implementation of telecommunication digital technologies, affects the technological, business, professional and publishing area of the communications media, which favors the integration of tools, spaces, working methods and languages that were formerly dispersed, so that journalists produce content that is distributed across multiple platforms, using the specific languages of each of them.
\end{abstract}

Although photojournalism follows suit in this pace of change, whether technological or methodological, which is generally perceived as a crisis in the industry, the nature of the activity is indeed also changing.

\begin{abstract}
This is the beginning of the end of a long decline. The traditional model of print distribution and direct editorial funding has been unravelling from the 1970s onwards, ever since weekly pictorial magazines like Life folded. This demonstrates photojournalism that required an editorial paymaster was in trouble long before the Internet was an issue or the global recession added to its woes. (CAMPBELL, 2010)
\end{abstract}

As a third point for reflection, in direct proportion to the depletion bias on funding based on the massive audience model, there is a compensation for models that incorporate a selective, direct audience that is a stakeholder to a particular ongoing project.

Therefore, we note that photojournalism borders on a synthesis of its precedent: proximity journalism. This synthesis become possible based on the concept of a more general use of media as enablers of social life (THOMPSON, 1995), which in turn creates new forms of interaction through symbolic recognition. Thus, the social role of media includes a loop that forms around spatial awareness in connection with issues whose levels of input and perception are closer to the individual, precisely because of factors of problem recognition relevant to the locale and the subjects with which they can relate on affective, social, cultural, and symbolic levels. Therefore, proximity can be understood as relative foundation for a field of shared interests within the audience; an approaching exercise that builds a two-way path between producers and readers, for the purpose of meeting a demand for plural approaches in lifestyles and viewpoints closer to plurality. 
The community, in the sense previously dealt with by Rheingold (1994), pervades the links of mutual symbolic belonging that are channelled towards a particular interest. Similar initiatives occur in music production chain, especially following the brutal rearrangement that this industry had over the last decade. However, to consider the transposition and adaptation of this articulation as a means of funding visual journalism is an unprecedented approach in the field of news information. Under this approach, the challenge posed by these initiatives is precisely the possibility of arranging users based on their specific interests, within circumstances marked by a multiplicity of supply and, at the same time, the organizational and aggregating potential of networks.

And what are some funding alternatives for contemporary photojournalism? Some proposals are based on the audience, for example, aiming to place the reader (or user?) at the top of the chain, and seeking to integrate them into the core of the content production process. One of the models to this end is based on crowdfunding, a collective effort which leverages cooperation, attention and trust to raise funds, usually via the Internet, for the purpose of supporting efforts initiated by other people or organizations. It has its origins in the very concept of charity, and has currently gained renewed attention as social networks, online communities, and micropayment systems facilitate the receipt and management of resources, and strengthen bonds between participants and donors.

On the following pages, we review two Web sites ("Flattr" and "Emphas.is") that propose to address journalistic practices by using a similar approach. Can they be regarded as (good) alternatives to the alleged current crisis in photojournalism?

\subsection{Flattr: "Many small streams will form a large river"}

Currently on its trial or "beta version", this "content funding microplataform" operates as follows: by making deposits into an account operated from the project Web site (for a minimum investment of about two euros), registered users may fund initiatives in a range of fields, including, but not limited to, photography, film, advertising, and journalistic investigation. Based on a bold proposal (the idea that users' affinity with the selected products drives a new niche market on the Web), "Flattr" brings content production even closer to consumers. According to the Web site creators: 


\begin{abstract}
Every month, the Flattr user pays a small fee. Let's compare it with birthday cake. When you have a cake, you want to give slices to the people you like. Flattr helps you do that. If you've created something, you can add a Flattr to your content. Or if you find something you like, and there's a Flattr button beside the content, you click it. Each button has a counter showing how many people are willing to give cake for the content. At the end of the month, your cake is sliced in as many pieces, as you click Flattr buttons. Each slice is then given to the correct content creator. If you click ten buttons, the ten creators will get a tenth of the cake each. If you click a hundred buttons, the hundred creators will get a hundredth of the cake. The slices might be small, but everyone's will all add up.
\end{abstract}

Figure 2 "Flattr" home page (www.flattr.com)

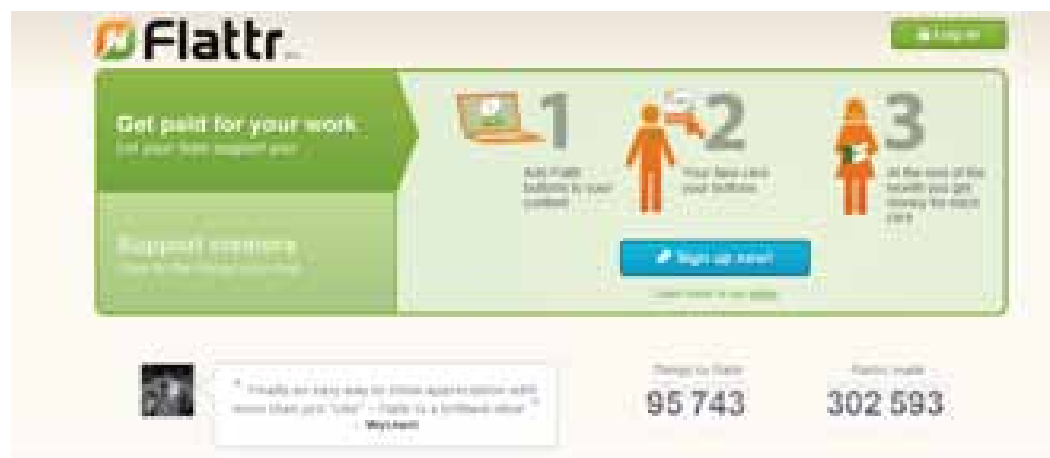

Unlike traditional funding models, which combine advertising with content, the Flattr platform does not seek to use funds from external sources to support content. Instead, it relies on its ability to spread quickly over the worldwide computer network to welcome projects matching its standards to seek the required resources for execution. The more Flattr users promote their projects on social networks, Web sites and search engines, the more likely projects get recommendations that can potentially result in more resources to support their idea. Again, there is a clear separation between producing and funding sources, a model that was well-established among large news and communications corporations, for example.

The wide circulation of multimedia content through the conscious action of multiple networks of consumers/participants tends to create greater visibility and awareness, since content flows in the right direction toward reaching people that can potentially be interested in committing further with producers. Take, for example, portable media 
devices, multimedia mobile telephones (smart phones), or multimedia tablets. Beyond the technologies, resources and applications that power these devices, it is the social dynamics that will drive the information flow and bring those interfaces to life (JENKINS, 2010).

With regard to photojournalism, some examples already point out interesting paths. Among them is a photo essay on North Korea (Secrets and Lies) by Belgian photojournalist Tomas Van Houtryve, who used the Flattr platform to raise funds. In his teaser, Van Houtryve made the pictures available on the web and associated them to a tool that allowed users to make donations through Flattr. As a result, he received 3,300 recommendations, which earned him a total 1,700.26 euros.

From Aug. 6 to Sept. 6 2010, I received 3300 Flattrs on the North Korea photo essay that I initially posted for testing. That turned into 1700.26 Euros, for an average of 0.52 Euros per Flattr. Over the same period, the NK photo essay had 111175 page views. If I am doing the math correctly, that means that I had one Flattr for every 36 page views.

Figure 3 Home page of the photographic essay on North Korea

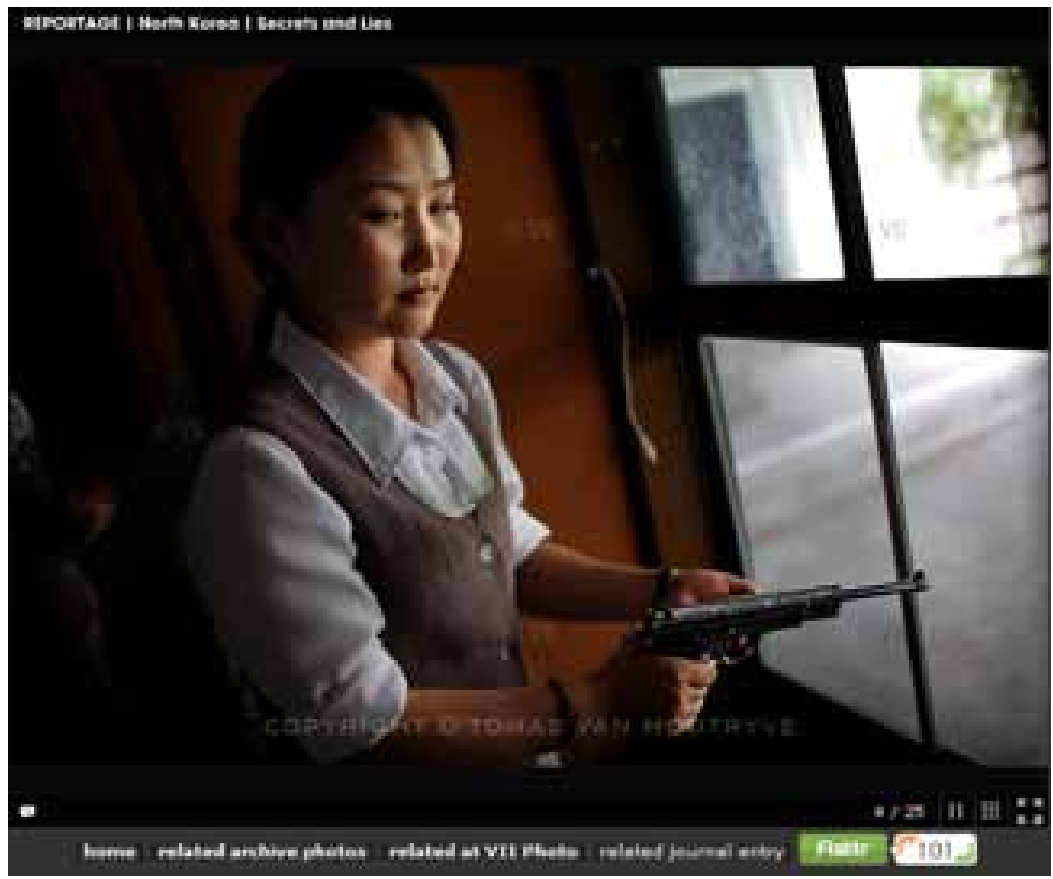




\title{
1.2 Emphas.is: new frontiers in photojournalism?
}

With a specific focus on photojournalism, this platform seeks to establish an intimate connection between the audience and content producers, based on the audience-funded model (crowdfunding), like the Flattr micropayment Web site. The concept lies in that proposals for content production are made publicly available on the Web site, and the audience is free to choose to invest in the project that most appeals to them. The purpose is to find resources to fund the whole process, not just the final product.

However, unlike other proposals, which do not offer a direct return on investment for the user (i.e., the finished product), Emphas.is provides exclusive access for the user to retrieve pictures, videos, work materials, and other benefits. Furthermore, real-time content and use of social networks to monitor the creative process is also provided as a service offering. Note that it is photojournalists who may, at their sole discretion, choose whether or not to make these materials available, rather than the Emphas.is platform.

\begin{abstract}
No longer does the reader want to receive this pre-formatted information that is part of a one-way communication model. Most readers are looking for information that is relevant for them; they want to actively participate and share ideas on the content offered, and most of all, they rely on their social networks to stay informed. Readers rely more and more on personal accounts than on objective reporting; they are looking for recommendations from people close to them; they want to decide how thoroughly stories will be told; they want to discuss and help shape stories. With Emphas.is, we try to take all these trends into account and make the reader/ viewer an active partner in the production process, rather than a mere consumer. (GARAPA, 2010)
\end{abstract}

According to Michael Kamber, a New York Times photographer with several works set in Iraq, Afghanistan, Sudan, and other countries, the Emphas.is platform represents new horizons for photojournalism. Kamber is excited about the possibilities. In his opinion, one of the most important features of the platform is the ability to reach people who really are interested in causes that often don't appeal to traditional media coverage. As an example, he mentions a young photographer from Yemen, Amira Al Sharif, who wanted to depict the situation of women in America. At first, Kamber admits, he was skeptical about trying to raise funds on the web. However, was quite impressed by the results: it took Amira less than a week to raise the five thousand dollars that she needed. He was so surprised that he decided to invest in his own personal project on the Web site as soon as it is officially released. 
If you ask me, what is happening in the media today is not even a result of the global financial crisis. The crisis has only accelerated an existing trend. Newspapers have become part of huge media conglomerates that are no longer about making a profit but about maximizing profit, and everything that stands in the way of profit maximization is simply being tossed out. (EMPHAS.IS, 2011)

Figure 4 Emphas.is home page

\section{emphas.is}

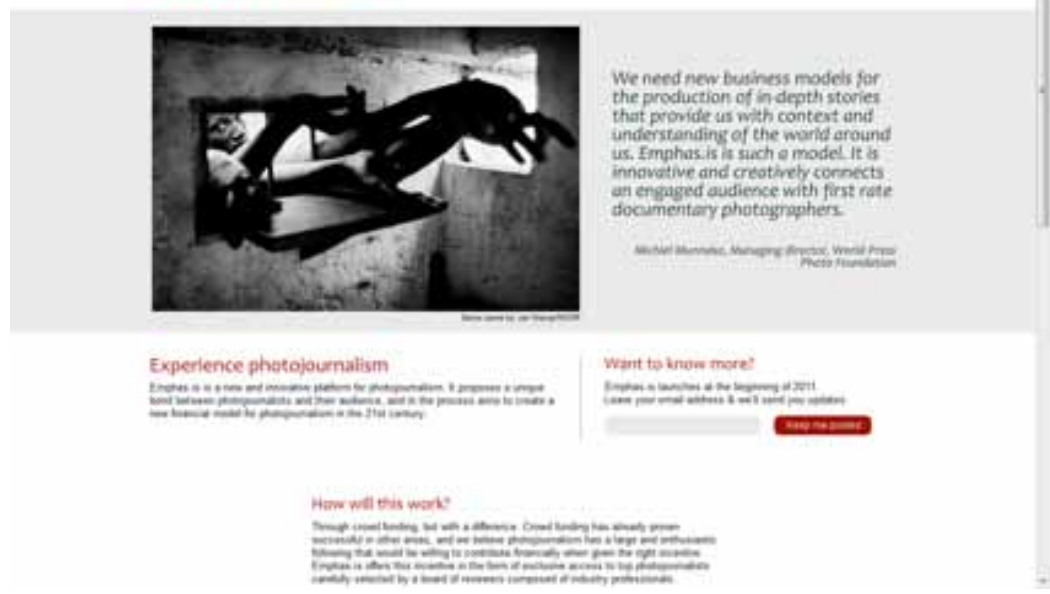

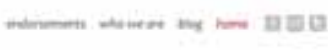

\section{CONCLUSIONS}

To redefine models, to rethink products, partners and customers - this is the challenge facing photojournalism in the digital convergence era. In contrast with a judging stance that sees the current scenario as a crisis, alternative funding models are actively proposed for the activity. In short, what actually seems to be collapsing are conservative standards dating back to the twentieth century, which stick to obsolete models of photojournalism funding. On the other end of the process, photojournalism remains creative, innovative, and successful in fulfilling its ethical role of providing a visual account of a story or piece of news. At the focal point of these questions, which are already re-shaping photojournalism as an activity, the debate finally reaches maturity as it transcends the realms of technology, cognitive and infrastructure issues. The funding model itself is now considered as it links with the concepts 
of digital convergence, interaction and audience participation, biased by a sustainability-oriented praxis in this new scenario.

As shown in the examples above, changes in the circulation chain of photojournalism are already evident. Thus, the traditional content funding model, in which advertisement was at the core of financial management of the media outlets, is being redesigned. Today, readers are no longer satisfied by merely consuming information: they want to actively engage in the process by acting as producers or - as in the sample cases presented - they look out for interesting projects to fund. A new consumer profile emerges in photojournalism.

However, we are still talking about trends. Other tangible examples already exist. In this regard, project Latitude is worth mentioning. This is an application that runs on the iPad mobile platform and consists of a mixed form combining features of an application, a photography magazine, and an access platform which provide both a window of visibility for the Latitude collective and a business model. Interestingly, this model departs from the web as a place of visibility. In its iPad format, it works as an off-web business model, although it is still made available on the internet. Thus, it directs and channels the flow from the user to product to platform. It provides an alternative which, within the ambiguities of convergent media models, makes it natural to try to combine the ability to rely on an independent funding source for production with the idea of a paid magazine based on the traditional model, but without the moorings of the publishing industry.

Figure 5 Latitude project overview screens on iPad
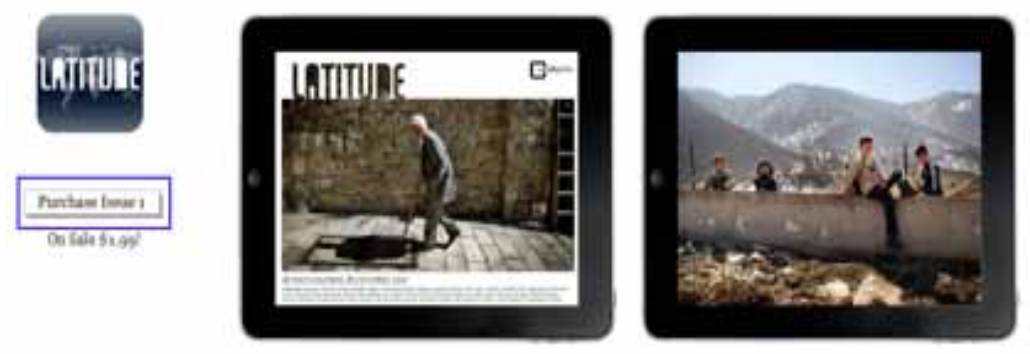

The Latitude app can be downloaded for free from the iPad management system, iTunes. Once downloaded, it provides the user with access to an overview of the collective and samples of the material; for example, the "41 photographers, 36 countries, 1 day" essay. Other 
essays are available for download through a micropayment system at $\$ 1.99$ each issue. It is a business strategy that focuses on low-cost access to the material from the perspective of a broad consumption horizon.

To sum up the general hypotheses of this paper, we analyze some points. The detente between content production and its funding seems to take the first steps towards establishing themselves on different poles of the equation. A naive look might even detect the beginnings of editorial independence for photojournalism. A similar viewpoint was commonly found when the Internet emerged 15 years ago, as it was believed that any user could potentially have a communication medium of their own and publish anything they wanted to. If this were true, it would also be true that the models would be inherently sustainable.

In fact, there is a misconception in that technological requirements alone are believed to provide sustainable models. However, this support relies precisely on a combination of various situational, conceptual and technological factors. Additionally, even if the financing model is to be found within these new foundations, it does not supersede the symbolic exchange between those who provide the source of funding and those who provide the images. Those who hire the orchestra still choose the music that will be played, and the contract terms of photography as a mode of communication cannot be separated from this axis. Thus, compensatory exchanges between funding and production can occur in the form of new content production, thematic agendas, etc., but do not disappear at all.

As it turns out outright, it would be rash to claim that these experiences are incorporated to the regular traditional media chain. We must consider that the success of these alternatives is still delimited by models that are centrifugal to the pre-formatted organization of the content industry. To consider a direct transposition is not quite an applicable interpretation, since the history of photojournalism points to gradual and systematic assimilations. Thus, the bias created by funding models draws on previous ones, not in order to completely void them, but in a way that opens valves that can oxygenate the productive press photography chain.

In addition, by seeking sustainability outside the models of massive audience and diversifying into multi-platforms, one clearly attempts to skip cultural industry outlets that intermediate the dynamics between content and audience.

Going forward, to conceive photojournalism and its circulation as a mostly circumstantial arrangement that can be actuated at any 
time - or simply put, as a process rather than a product - is somewhat like swallowing a poisoned toffee while disregarding the recurring and universal character of information and collective and massive circulation as essential elements in understanding the role of news photography in the visual and social construction of reality.

The mistake lies precisely in believing that the full separation between content, platform and circulation would be a guarantee of sustainability. In other words, we continue to have access to photos and reports made 50, 70 years ago; however, how can we ensure that new experiments that run on iPad, for example, will still be accessible within 20 or 30 years?

The reasonable, feasible formula seems to be combining new funding models, such as crowdfunding, with current models, which does not absolutely preclude either of two possible outcomes - first, restructuring and adjusting traditional models, for example, by hiring collectives to create special materials for newspapers (QUEIROGA; SILVA JR, 2010); second, adhering to the new funding models while keeping them free from the onset of hegemonic trends within this perspective.

Finally, it is nonetheless important to mention the emergence of this set of financing alternatives as a readiness for innovation in funding photojournalism. This is where ambiguities emerge. It implies one natural adjustment among many others in the history of photojournalism. Being aware of the market stresses and strains and of models that compete with the production model is precisely what helps solve these ambiguities.

Moreover, keeping these ambiguities in mind helps to understand what the influential factors in this convergence scenario make of this kind of articulation. Let us not forget that, in a way, the elements and issues presented here govern how photojournalism is funded, to the same extent that other models will very likely emerge over time, incorporate and readjust themselves.

Thus, perhaps the funding models for convergent contemporary journalism cannot ensure, nor are alone an attempt to overthrow the established production routines of photojournalism. Rather, they certainly leave room for new points of negotiation in the productive chain. This is one more chapter in the story of how news, technology, society and images get along together - and how it pays off. 
AHRENS, Tina; DEWEVER, Fanuel; BOUTSEN, Gunter. Emphas.is. Available at: http://www.emphas.is/home.html. Accessed on: Dec. 10, 2010.

ALTERMAN, Eric. Save the news, not the newspaper. Available at: http:// www.thenation.com/article/save-news-not-newspaper. Accessed on : Dec. 10, 2010.

ANDERSON, Chris. A Cauda Longa: do mercado de massa para o mercado de nicho. Translated by Afonso Celso da Cunha Serra from the original "The Long Tail”. Rio de Janeiro, Elsevier, 2006.

BAPTISTA, Eugênio Sávio Lessa. Fotojornalismo Digital no Brasil: a imagem na imprensa da era pós-fotografia. Master's dissertation. Universidade Federal do Rio de Janeiro. 2000.

BUITONI, Dulcília Helena Schroeder. Imagens semoventes: fotografia e multimídia no webjornalismo. Conference paper, XXX Congresso Brasileiro de Ciências da Comunicação. Santos, 2007.

CAMPBELL, David. Photojournalism in the new media economy. Nieman Reports, 2010.

CASTELLS, Manuel. A era da informação: economia, sociedade e cultura. Vol 1: a sociedade em rede. São Paulo: Paz e Terra, 1999.

FAVILLA, André Luis. A imagem híbrida: a síntese entre o universo fotográfico e o digital. Master's dissertation. Universidade Estadual de Campinas,1998.

FLATTR: social micropayments. Available at: http://flattr.com/. Accessed on: Nov. 20, 2010.

GARAPA. Interview with Tina Ahrens, Emphas.is. Available at: http:// garapa.org/2010/10/entrevista-tina-ahrens-emphas-is/. Accessed on: Nov. 20, 2010.

GITLIN, Tood. Journalism's many crises. Available at: http://www. opendemocracy.net/article/a-surfeit-of-crises-circulation-revenue-attentionauthority-and-deference. Accessed on: Nov. 20, 2010.

JENKINS, H. Convergence Culture. Where Old and New Media Collide. New York: New York University Press. 2006.

LAWSON-BORDERS, Gracie. Media organizations and convergence: case studies of media convergence pioneers. New Jersey, LEA Publishers. 2006.

LANGTON, Loup. Photojournalism and today's news: creating visual reallity. Oxford: Wiley-Blackwell, 2009.

MITCHELL, William. The Reconfigured Eye. Visual truth in the post 
photographic era. Cambridge, MA, Mit Press, 1994.

MUNHOZ, Paulo César Vialle. Fotojornalismo, internet e participação: os usos da fotografia em weblogs e veículos de pauta aberta. Salvador, 2005. Master's dissertation.

RITCHIN, Fred. After Photography. WW. Norton \& Company, 2009.

SILVA JUNIOR, José Afonso. Permanência e desvio no fotojornalismo em tempo de convergência digital: elementos para uma discussão preliminar. Conference paper, XXXI Congresso Brasileiro de Ciências da Comunicação. Natal, 2008.

SILVA JR, José Afonso, QUEIROGA, Eduardo. Fotojornalismo Colaborativo em Tempo de Convergência. Brazilian Journalism Research Vol.6-N2. 2010. Available at: http://bjr.libertar.org/index.php/bjr/article/view/27. Accessed on: Feb. 7, 2011.

SOUSA, Jorge Pedro. Uma História Crítica do Fotojornalismo Ocidental. Chapecó: Argos; Florianópolis: Letras Contemporâneas, 2004.

The state of news media: an annual report on American journalism. Available at: http://www.stateofthemedia.org/2009/narrative_newspapers_audience. php?cat=2\&media=4. Accessed on: Dec. 10, 2010.

USHER, Nikki. Why spreadable don 't equal viral: A conversation with Henry Jenkins. Available at: http://www.niemanlab.org/2010/11/why-spreadabledoesnt-equal-viral-a-conversation-with-henry-jenkins/. Accessed on: Dec. 15, 2010.

VAN HOUTRYVE, Tomas. Secrets and lies. Available at: http:// tomasvanhoutryve.com/reportage/north_korea/. Accessed on: Dec. 15, 2010.

José Afonso da Silva Junior PhD, Contemporary Communication and Culture, FACOM-UFBA (2006). Postdoctor, Universitat Pompeu Fabra, Barcelona, Spain, CAPES Fellowship (2010-2011). Associate Professor, PPGCOM-UFPE.

Email: zeafonsojr@gmail.com

João Guilherme de Melo Peixoto PhD Candidate, Communication, PPGCOM-UFPE. 
BETWEEN BITS AND DOLLARS 